\title{
Cytoprotective effect of Semecarpus anacardium against toxicity induced by Streptozotocin in rats
}

\author{
This article was published in the following Dove Press journal: \\ Journal of Experimental Pharmacology \\ 25 August 2010 \\ Number of times this article has been viewed
}

\author{
Jaya Aseervatham' \\ Shanthi Palanivelu ${ }^{2}$ \\ Panchanadham Sachdanandam' \\ 'Department of Medical Biochemistry, \\ ${ }^{2}$ Department of Pathology, Dr ALM \\ Post Graduate Institute of Basic \\ Medical Sciences, University of \\ Madras, India
}

Correspondence: Panchanadham

Sachdanandam

Department of Medical Biochemistry, Dr ALM Post Graduate Institute of Basic Medical Sciences, University of Madras, Taramani Campus, Chennai 600 I I 3, India Fax +9I 4424540709

Email psachdanandam2000@yahoo.co.in

\begin{abstract}
Leakage of cellular enzymes into the plasma is a clear indication of cell damage. When liver plasma membrane is damaged, a variety of enzymes normally located in the cytosol are released into the blood stream and their estimation is a quantitative marker for the extent of damage. The cytoprotective effect of Semecarpus anacardium was evaluated in rats that were rendered diabetic by administration of streptozotocin at a dose of $50 \mathrm{mg} / \mathrm{kg}$ body weight. The activities of the marker enzymes were assayed in the serum, liver and kidney. The indicators of renal damage such as urea, uric acid and creatinine were assayed in addition to the blood profile. The results of the present study reveal that Semecarpus anacardium was able to reverse the levels of the marker enzymes, and protect the kidney by reverting back to the normal levels of urea, uric acid, and creatinine. The abnormal blood parameters were also reverted to near normal levels indicating the drug's cytoprotective effect.
\end{abstract}

Keywords: marker enzymes, Semecarpus anacardium, blood profile, cytoprotective effect

\section{Introduction}

Diabetes mellitus is probably the single most important metabolic disease and is widely recognized as one of the leading causes of death and disability. It affects every cell in the body and the body's essential biochemical processes, and it is a major public health problem in developed as well as developing countries. ${ }^{1}$ Diabetes arises due to a deficiency of insulin secretion from the beta cells of the pancreas or a deficiency of insulin action. The endocrine pancreas is arranged in clusters of secretory cells in the islets of Langerhans. It contains about one million islets that comprise $1 \%-2 \%$ of the total mass of the gland. These islets are separated from the exocrine tissue by a capsule made up of connective tissue fibers and glial like cells. ${ }^{2}$ Four different endocrine cell types are contained in the islets: $\beta$ cells, which produce insulin and constitute $60 \%-80 \%$ of the endocrine cell mass, glucagon-secreting $\alpha$ cells $(10 \%-20 \%)$, somatostatin-producing d-cells $(\sim 5 \%)$ and pancreatic polypeptide-secreting PP-cells $(<1 \%){ }^{3}$

Streptozotocin (STZ) is a metabolite of the soil organism Streptomyces achromogenes. Owing to a structural resemblance to D-glucose it is taken up by the glucose transporter (GLUT2), which is expressed in the pancreas, liver and the kidney of rodents. ${ }^{4}$ Beta cell necrosis can be detected by electron microscopy within a few hours after STZ administration. ${ }^{5}$ Intracellular action of STZ results in nitric oxide (NO) liberation, alkylation, and fragmentation of DNA, leading to cell death. DNA damage activates poly ADP-ribosylation which leads to the depletion of cellular NAD+, reduc- 
tion of ATP, and subsequent inhibition of insulin synthesis and secretion. Six hours after STZ injection, hyperglycemia develops and blood insulin levels decrease. ${ }^{7}$

The use of medicinal plants for the treatment of diabetes mellitus dates back from the Ebers papyrus of about $1550 \mathrm{BC}$. A multitude of herbs, spices, and other plant materials have been described for the treatment of diabetes throughout the world. ${ }^{8}$ Semecarpus anacardium Linn., commonly called marking nut, is found in the outer Himalayas and the hotter parts of India. Its bark is an astringent and the tree exudes a gum which is used in leprous infections and nervous debility. The chloroform extract of the nut possesses antitumor action against L1210, P388, advanced P388 leukemia, B16 melanoma, and glioma $26 .{ }^{9}$ It also potentiates the efficacy of widely used anticancer drugs, viz, mitomycin C, 5-fluorouracil and methotrexate. ${ }^{10} \mathrm{~A}$ marking nut preparation, SAN-AB was shown to bring about complete inhibition of tumor growth in rats. Analysis of the kernel revealed the presence of protein 26.4, fat 36.4, fiber 1.4, other carbohydrates 28.4 and minerals 3.6, Ca 29.5, P 83.6, Fe $6.1 \mathrm{mg} / 100 \mathrm{~g}$ and essential amino acids like leucine, isoleucine methionine etc. Phytochemical analysis revealed the presence of biflavonoids, phenolic compounds, ${ }^{11}$ bhilawanols, ${ }^{12}$ sterols and glycosides in Semecarpus anacardium nuts. On the basis of chemical and spectral data, several biflavonoids such as semecarpuflavanone, jeediflavanone, galluflavanone, nalluflavanone, semecarpetin, and anacardiflavanone ${ }^{13}$ have been characterized. Monophenolic compounds known as semecarpol $\left(\mathrm{C}_{17} \mathrm{H}_{28} \mathrm{O}\right)$ and bhilawanol were also isolated. Vijayalakshmi et al ${ }^{14}$ have also reported the presence of carbohydrates, phenols, and flavonoids in the Siddha preparation. The chloroform and milk extract of the nut was found to be active in adjuvant-induced arthritis ${ }^{15}$ and various types of cancers. ${ }^{16}$ It also has hypoglycemic, ${ }^{17}$ antioxidant, ${ }^{18}$ anti-inflammatory, and COX inhibitory properties. ${ }^{19}$ The present study was undertaken to evaluate the cytoprotective effect of Semecarpus anacardium against the toxicity induced by streptozotocin in rats by using biological markers, since they permit the early identification of the adverse effects and the potentiality of the drug used in the treatment of diseases.

\section{Material and methods}

The drug Semecarpus anacardium (SA) nut extract contains purified nuts of Semecarpus anacardium and cow's milk in the ratio as indicated in the Formulary of Siddha Medicine. $200 \mathrm{~g}$ of the nut was boiled with $500 \mathrm{~mL}$ of milk, which was repeated thrice. The decoction was stored at room temperature. ${ }^{20}$

\section{Animals}

Male albino rats of Wistar strain, 8-10 weeks old, weighing $260 \pm 10 \mathrm{~g}$ were used in this study. The animals were housed in polypropylene cages under a control environment with 12-hour light/dark cycles and a temperature between 27 and $37^{\circ} \mathrm{C}$, and were given a commercial diet with water ad libitum. All experiments involving animals were conducted according to NIH guidelines, after obtaining approval from the Institute's Ethical Committee $(02 / 075 / 06)$.

\section{Experimental design}

Rats were divided into five groups of six animals each.

Group 1, control animals: Normal healthy controls received olive oil $(0.5 \mathrm{~mL})$ orally by gastric intubation for 21 days daily.

Group 2, diabetes induced: Streptozotocin $(50 \mathrm{mg} / \mathrm{kg}$ body weight) dissolved in $0.5 \mathrm{~mL}$ of $0.1 \mathrm{M}$ citrate buffer $\mathrm{pH} 4.5$. Group 3, SA treated: Three days after the induction of diabetes, SA $(300 \mathrm{mg} / \mathrm{kg}$ body weight dissolved in $0.5 \mathrm{~mL}$ olive oil) was administered by gastric intubation for 21 days daily.

Group 4, metformin treated: Three days after the induction of diabetes, metformin $(500 \mathrm{mg} / \mathrm{kg}$ body weight dissolved in $0.5 \mathrm{~mL}$ physiological saline) was administered by gastric intubation for 21 days daily.

Group 5, drug control: Animals received SA $(300 \mathrm{mg} / \mathrm{kg}$ body weight dissolved in $0.5 \mathrm{~mL}$ olive oil) orally by gastric intubation for 21 days daily.

\section{Biochemical analysis}

After the experimental period, the animals were killed by cervical decapitation. The pancreases were excised immediately and immersed in ice-cold physiological saline. Ten percent homogenate was prepared with fresh tissue in $0.01 \mathrm{M}$ tris-HCl buffer ( $\mathrm{pH}$ 7.4) and these were used for the assays. Blood was collected, the serum was separated and also used for the analysis.

\section{Hematological indices}

Red blood cell count (RBC) and white blood cell count (WBC) were done according to the method of Chesbrough and McArthur ${ }^{21}$ in an improved Neubauer chamber. Platelets were counted using the improved Neubauer counting chamber by the method of Dacie and Lewis. ${ }^{22}$ Packed cell volume (PCV) was estimated by the Wintrobe macro method. ${ }^{23}$ Erythrocyte sedimentation rate (ESR) was estimated by the 
method of Westergren. ${ }^{24}$ Hemoglobin content in blood was estimated by the method of Drabkin and Austin. ${ }^{25}$ The mean volume of the red cell in terms of cubic microns was calculated from the formula:

$$
\text { M.C.V. }=\frac{\text { Hematocrit }(\text { volume of packed red cells })}{\mathrm{RBC} \text { in millions } / \mathrm{mm}^{3} .} \times 10
$$

$\mathrm{MCH}$ is the average quantity of hemoglobin in each corpuscle.

$$
\text { M.C.H. }=\frac{\mathrm{g} \mathrm{Hgb} / 100 \mathrm{~mL} .}{\mathrm{RBC} \text { in millions } / \text { cu.mm. }} \times 10
$$

M.C.H.C was calculated from the following formula.

$$
\text { M.C.H.C. }=\frac{\mathrm{g} \mathrm{Hgb} / 100 \mathrm{~mL}}{\text { Hematocrit }} \times 100
$$

\section{Estimation of the enzymes involved in cellular integrity}

Alanine and aspartate aminotransferases were assayed by the method of King; ${ }^{26}$ alkaline phosphatase activity (ALP) was assayed by the method of King ${ }^{27}$ gamma-glutamyl transpeptidase (GGT) was assayed by the method of Orlowski and Meister; ${ }^{28} 5$ ' nucleotidase (5-'NT) was assayed by the method of Luly et al ${ }^{29}$ albumin was estimated by the method of Fine; $;^{30}$ total bilirubin was estimated by the method of Dangerfield and Finlayson; ${ }^{31}$ amylase was estimated by the method of Henry and Chiamori. ${ }^{32}$

\section{Estimation of renal function parameters}

Urea was estimated by the method of Natelson et al; ${ }^{33}$ uric acid was estimated by the method of Caraway; ${ }^{34}$ creatinine was estimated by the method of Owen et al. ${ }^{35}$

\section{Histopathological observations in the liver of control and experimental animals}

All histopathological studies for liver were performed using standard procedures with uniform conditions of fixation and staining of $5-\mu \mathrm{m}$ sections with hematoxylin and eosin (H\&E).

\section{Statistical analysis}

The values are expressed as mean \pm SD for six rats in each group. Statistically significant differences between the groups were calculated using one-way analysis of variance (ANOVA), followed by Student Newman - Keuls for multiple comparisons using a statistical package for social sciences (SPSS) computer package. Values of $P<0.05$ were considered to be significant.

\section{Results}

\section{Effect of SA on hematological indices}

Study of hematological status is one of the important ways for the diagnosis of the root cause of diseases. Alterations in blood parameters may be due to changes in cellular integrity, membrane permeability, and metabolism, or even due to exposure to toxic chemicals.

The blood profiles of control and experimental animals

\begin{tabular}{|c|c|c|c|c|c|}
\hline Parameters & $\begin{array}{l}\text { Group I } \\
\text { (control) }\end{array}$ & $\begin{array}{l}\text { Group } 2 \\
\text { (STZ) }\end{array}$ & $\begin{array}{l}\text { Group } 3 \\
\text { (STZ + SA) }\end{array}$ & $\begin{array}{l}\text { Group } 4 \\
\text { (STZ + metformin) }\end{array}$ & $\begin{array}{l}\text { Group } 5 \\
\text { (SA) }\end{array}$ \\
\hline $\begin{array}{l}\mathrm{RBC} \times \\
\left(10^{6} / \mathrm{mm}^{3}\right)\end{array}$ & $7.37 \pm 0.71$ & $5.31 \pm 0.59^{a, *}$ & $7.05 \pm 0.72^{\mathrm{b}, *}$ & $6.76 \pm 0.63^{\mathrm{b}, *, \mathrm{c}, *}$ & $7.4 I \pm 0.8 I$ \\
\hline $\begin{array}{l}\text { Total WBC } \\
\times\left(10^{3} / \mathrm{mm}^{3}\right)\end{array}$ & $6.22 \pm 0.6 \mathrm{I}$ & $8.31 \pm\left. 0.9\right|^{a, *}$ & $6.91 \pm 0.64^{\mathrm{b}, *}$ & $7.74 \pm 0.82^{b, *, c, *}$ & $6.18 \pm 0.59$ \\
\hline $\begin{array}{l}\text { Platelet count } \\
\times\left(10^{3} / \mathrm{mm}^{3}\right)\end{array}$ & $953.10 \pm 98.15$ & $1121.83 \pm 100.14^{a, *}$ & $979.52 \pm 89.45^{\mathrm{b}, *}$ & $1034.25 \pm 115.15^{\mathrm{b}, *, c, *}$ & $954.59 \pm 98.74$ \\
\hline PCV (\%) & $41.6 \pm 3.84$ & $33.07 \pm\left. 2.9\right|^{\mathrm{a}, *}$ & $39.32 \pm 3.12^{\mathrm{b}, *}$ & $37.13 \pm 3.97^{\mathrm{b}, *,,, *, *}$ & $42.13 \pm 4.12$ \\
\hline $\mathrm{Hb}(\mathrm{g} / \mathrm{dL})$ & $14.23 \pm 1.43$ & $8.72 \pm 0.96^{a, *}$ & $13.87 \pm 0.14^{\mathrm{b}, *}$ & $11.86 \pm 1.12^{\mathrm{b}, *,,, *}$ & $14.05 \pm 1.33$ \\
\hline ESR $(\mathrm{mm} / \mathrm{hr})$ & $9.97 \pm 0.10$ & $|3.80 \pm 1.4|^{\mathrm{a}, *}$ & $10.05 \pm 1.18^{\mathrm{b}, *}$ & $11.67 \pm 0.99 \mathrm{~b}, *, c, *$ & $10.16 \pm 1.32$ \\
\hline MCV (fl) & $56.44 \pm 5.52$ & $58.45 \pm 5.73^{\mathrm{a}, *}$ & $55.74 \pm 5.21^{\mathrm{b}, *}$ & $54.23 \pm 5.42^{\mathrm{b}, *,,, *}$ & $56.89 \pm 5.38$ \\
\hline $\mathrm{MCH}(\mathrm{pg})$ & $19.23 \pm 1.88$ & $16.46 \pm 1.72^{\mathrm{a}, *}$ & $19.75 \pm 1.86^{\mathrm{b}, *}$ & $17.25 \pm 1.68^{\mathrm{b}, *, c, *}$ & $19.43 \pm 1.91$ \\
\hline $\mathrm{MCHC}(\%)$ & $34.4 I \pm 3.5 I$ & $28.11 \pm 2.48^{\mathrm{a}, *}$ & $35.18 \pm 3.42^{\mathrm{b}, *}$ & $31.74 \pm 3.09 \mathrm{~b}, *, c, *$ & $33.37 \pm 3.16$ \\
\hline
\end{tabular}
are given in Table 1. The increase in WBC count (1.33-fold),

Table I Blood profile of control and experimental animals

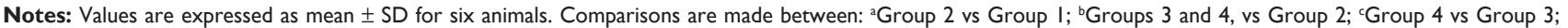
${ }^{d}$ Group 5 vs Group I; *statistical significance at $P<0.05$.

Abbreviations: RBC, red blood cell count; WBC, white blood cell count; PCV, packed cell volume; Hb, hemoglobin; ESR, erythrocyte sedimentation rate; MCV, mean corpuscular volume; $\mathrm{MCH}$, mean corpuscular hemoglobin; $\mathrm{MCHC}$, mean corpuscular hemoglobin concentration. 
platelet count (1.17-fold), ESR (1.38-fold), and MCV by 1.03-fold, and the decrease in RBC by $38.7 \%$, hemoglobin ( $\mathrm{Hb}$ ) by $38.72 \%, \mathrm{MCH}$ by $14.4 \%$, and $\mathrm{MCHC}$ by $53.08 \%$, shows the changes brought about diabetes in Group 2 animals. These changes were reverted back $(P<0.05)$ to near normal levels upon administration of SA and metformin. When Group 4 animals were compared with Group 3 animals significant difference $(P<0.05)$ between the two groups were observed with SA being more effective than metformin. No significant difference was observed when Groups 1 and 5 were compared.

\section{Effect of SA on marker enzymes in the serum, liver and kidney}

The level of marker enzymes in serum is given in Figure 1. Serum glutamic oxaloacetic transaminase (SGOT) increased by 1.37-fold, serum glutamic pyruvic transaminase (SGPT) by 2.8 -fold, ALP by 1.8 -fold, 5-'NT by 2.22 -fold and GGT by 1.60 -fold. These were restored to near normal levels upon administration of SA and metformin. Metformin-treated animals had higher values of marker enzymes $(P<0.05)$ when compared with SA-treated animals. Figures 2 and 3 shows the activities of ALT, AST, ALP, GGT, and 5-'NT in the liver and kidney of control and experimental animals. In diabetic untreated animals (Group 2) the activities of ALT, AST, GGT, ACP and 5-'NT were significantly increased $(P<0.05)$ when compared with Group 1 animals. Administration of SA (Group 3) and metformin (Group 4) to STZ-induced animals decreased the activities of the marker enzymes significantly $(P<0.05)$. No significant changes were observed when Group 1 and Group 5 animals were compared, whereas a significant

A

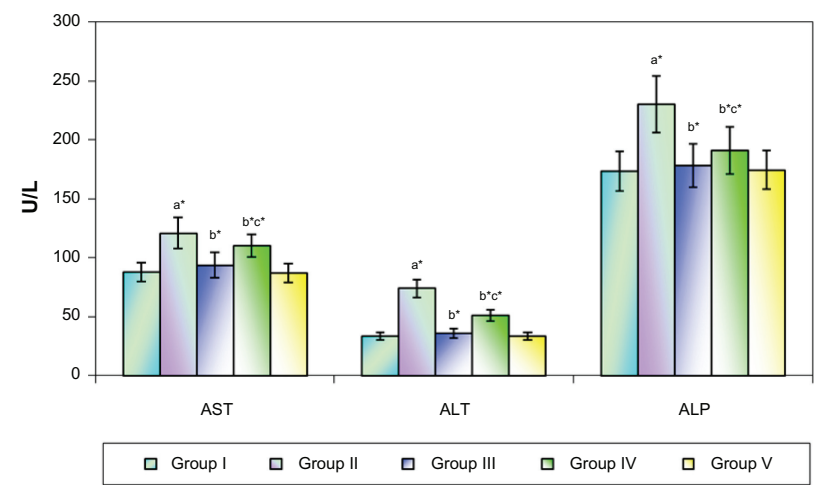

difference $(P<0.05)$ was observed between Group 3 and 4.

\section{Effect of SA on parameters in serum and urine}

Tables 2 and 3 shows the levels of albumin, A/G ratio, bilirubin, amylase in serum and urea, creatinine and uric acid in serum and urine of control and experimental animals. The increase in the level of bilirubin was 2.27-fold in Group 2 animals when compared with Group 1 animals which decreased by 0.46 -fold and 0.74-fold in Group 3 and Group 4 animals. The increase in albumin was 1.32-fold in Group 2 animals which decreased by 0.78 -fold in Group 3 and 0.89 fold for Group 4. A/G ratio in Group 2 animals decreased significantly $(P<0.05)$, which increased upon drug treatment $(P<0.05)$. Bilirubin and amylase increased by 2.27 - and 1.52 -fold in Group 2 animals and these levels were significantly decreased $(P<0.05)$ upon the administration of the drugs.

The levels of urea and creatinine in serum increased by 1.93-fold and 2.14-fold, and uric acid decreased by $50 \%$ in Group 2 animals. Upon SA treatment, urea and creatinine decreased by 1 -fold and 0.5 -fold whereas the level of uric acid increased by $96 \%$. In Group 4 animals the values of urea and creatinine decreased by 0.62 - and 0.73 -fold and uric acid increased by $52 \%$.

The levels of urea, creatinine, uric acid and albumin in urine increased significantly $(P<0.05)$ in Group 2 animals. These were reverted back to near normal levels upon administration of SA and metformin. Significant differences $(P<0.05)$ were found when SA and metformin treated groups were compared. For all the above given parameters there was no significant change when animals in Groups 1 and 5 were compared.

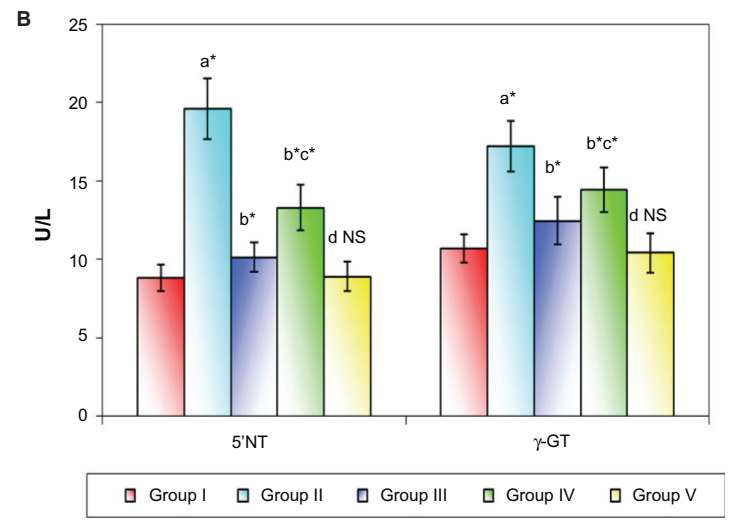

Figure I Levels of marker enzymes in the serum of control and experimental animals.

Notes: Values are expressed as mean \pm SD for six animals. Comparisons are made between: a'Group 2 vs Group I; 'broups 3 and 4, vs Group 2; 'Group 4 vs Group 3; ${ }^{d}$ Group 5 vs Group I; *statistical significance at $P<0.05$. 


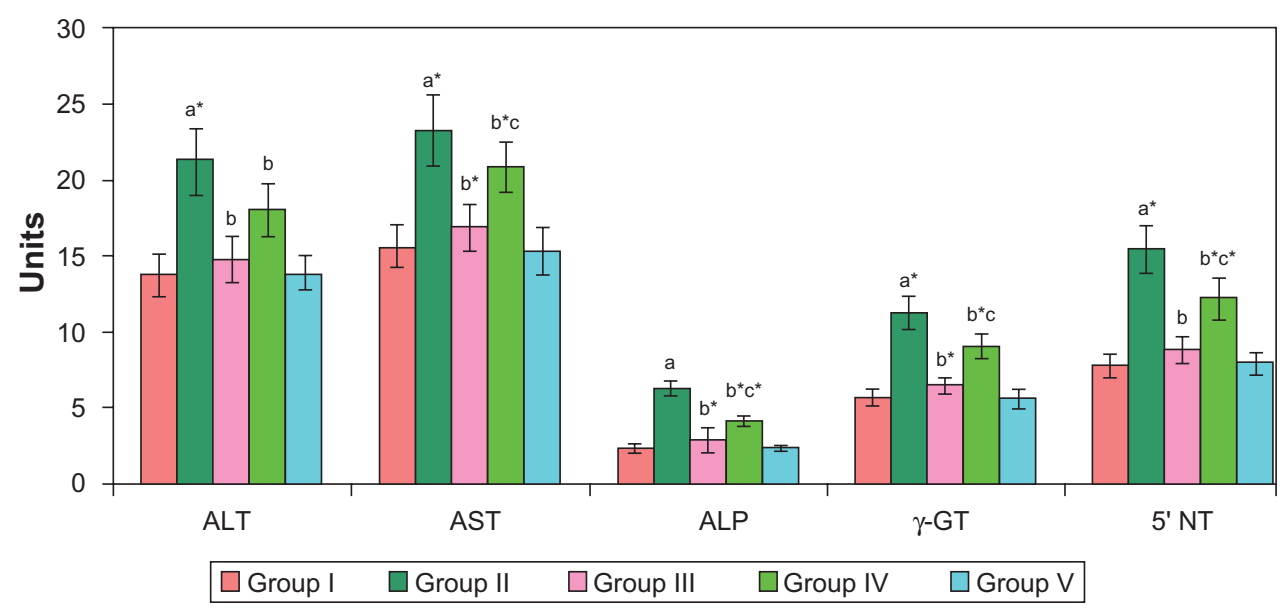

Figure 2 Marker enzymes in the liver of control and experimental animals.

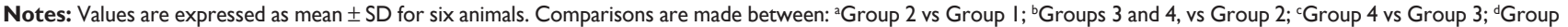
5 vs Group I; *statistical significance at $P<0.05$.

Units: AST, $\mu \mathrm{mol}$ of pyruvate liberated $/ \mathrm{min} / \mathrm{mg}$ protein; ALT, $\mu \mathrm{mol}$ of pyruvate liberated $/ \mathrm{min} / \mathrm{mg}$ protein; ALP, $\mu \mathrm{mol}$ of phenol liberated $/ \mathrm{min} / \mathrm{mg} \mathrm{protein} ; \mathrm{ACP}, \mu \mathrm{moles}$ of phenol liberated $/ \mathrm{min} / \mathrm{mg}$ protein.

\section{Histopathological observations in the liver of control and experimental animals}

Figure 4 shows the changes that are observed histologically in the liver of various groups of animals.

\section{Discussion}

In diabetes, hematological disorders play a substantial role in the pathogenesis of its complications. ${ }^{36}$ Reduced RBC count, $\mathrm{Hb}$ and hematocrit, in untreated diabetic rats indicate the progression towards anemia, which may be the result of impaired red blood cell production. ${ }^{37}$ The reduction in $\mathrm{Hb}$ is due to decreased formation of globulin or circulating failure, which decreases the circulatory blood volume. ${ }^{38}$ The decrease in $\mathrm{MCH}$ and $\mathrm{MCHC}$ values, observed after administration of STZ, is an indication of abnormal hemoglobin synthesis, failure of blood osmoregulation, and plasma osmolarity. ${ }^{39}$ These alterations in blood indices imply that the extract could alter the incorporation of haemoglobin into red blood cells as evident from the altered levels in Group 3 animals. Though metformin has the capacity to revert back the altered levels of blood volume in diabetic rats, ${ }^{40}$ the effect was not as pronounced as the plant extract. The profile of the WBC count reflects the balance between the rate of granulocyte production and that of WBC. Kozlov et $\mathrm{al}^{36}$ reported that diabetes in mice was accompanied by moderate neutrophilic leukocytosis, monocytopenia, depressed monocytopoiesis, prolonged circulation times of

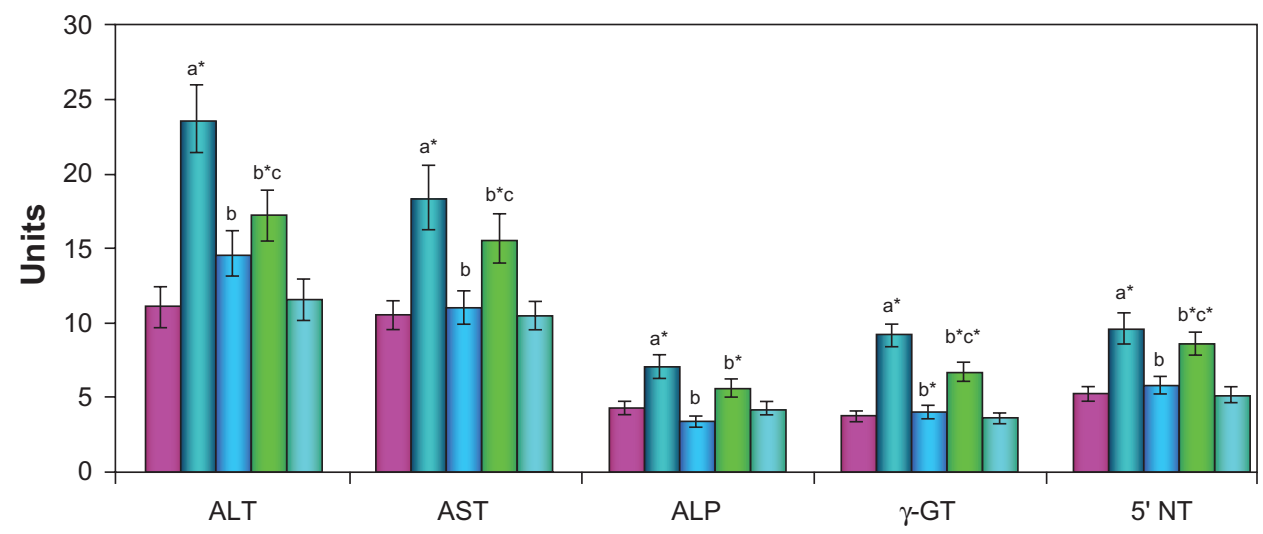

口Group I $\square$ Group II $\square$ Group III $\square$ Group IV $\square$ Group V

Figure 3 Marker enzymes in the kidney of control and experimental animals.

Notes: Values are expressed as mean \pm SD for six animals. Comparisons are made between: a Group 2 vs Group I; 'broups 3 and 4 , vs Group 2; 'Group 4 vs Group 3; ${ }^{d}$ Group 5 vs Group I; * statistical significance at $P<0.05$.

Units: AST, $\mu \mathrm{mol}$ of pyruvate liberated $/ \mathrm{min} / \mathrm{mg}$ protein, ALT, $\mu \mathrm{mol}$ of pyruvate liberated $/ \mathrm{min} / \mathrm{mg}$ protein, ALP, $\mu \mathrm{mol}$ of phenol liberated $/ \mathrm{min} / \mathrm{mg}$ protein; ACP, $\mu \mathrm{moles}$ of phenol liberated $/ \mathrm{min} / \mathrm{mg}$ protein. 
Table 2 Effect of SA on serum parameters of control and experimental animals

\begin{tabular}{|c|c|c|c|c|c|}
\hline Parameters & $\begin{array}{l}\text { Group I } \\
\text { (control) }\end{array}$ & $\begin{array}{l}\text { Group } 2 \\
\text { (STZ) }\end{array}$ & $\begin{array}{l}\text { Group } 3 \\
\text { (STZ + SA) }\end{array}$ & $\begin{array}{l}\text { Group } 4 \\
\text { (STZ + } \\
\text { metformin) }\end{array}$ & Group 5 (SA) \\
\hline Bilirubin (mg/dL) & $0.55 \pm 0.62$ & $1.25 \pm 0.14^{\mathrm{a}, *}$ & $0.58 \pm 0.56^{\mathrm{b}, *}$ & $0.93 \pm 0.97^{\mathrm{b}, * c, *}$ & $0.54 \pm 0.51$ \\
\hline Albumin (g/dL) & $3.61 \pm 0.31$ & $4.79 \pm 0.5 \mathrm{I}^{\mathrm{a}, *}$ & $3.78 \pm 0.39^{\mathrm{b}, *}$ & $4.27 \pm 0.47^{\mathrm{b}, * c, *}$ & $3.67 \pm 0.33$ \\
\hline A/G ratio & $4.53 \pm 0.34$ & $1.23 \pm 0.15^{\mathrm{a}, *}$ & $4.15 \pm 0.49^{\mathrm{b}, *}$ & $3.16 \pm 0.34^{b, *, c, *}$ & $4.13 \pm 0.42$ \\
\hline Amylase (U/L) & $4.22 \pm 0.39$ & $8.47 \pm 0.79^{a, *}$ & $4.68 \pm 0.5 \mathrm{I}^{\mathrm{b}, *}$ & $6.11 \pm 0.59^{\mathrm{b}, *, \mathrm{c}, *}$ & $3.16 \pm 0.34$ \\
\hline Urea (mg/dL) & $28.7 \pm 2.92$ & $55.5 \pm 5.62^{\mathrm{a}, *}$ & $32.17 \pm 3.04^{\mathrm{b}, *}$ & $43.94 \pm 3.98^{\mathrm{b}, *, \mathrm{c}, *}$ & $28.07 \pm 2.61$ \\
\hline Uricacid (mg/dL) & $3.11 \pm 0.30$ & $1.53 \pm 0.17^{\mathrm{a}, *}$ & $3.01 \pm 0.26^{\mathrm{b}, *}$ & $2.33 \pm 0.22^{b, *, c k}$ & $3.16 \pm 0.34$ \\
\hline Creatinine $(\mathrm{mg} / \mathrm{dL})$ & $0.75 \pm 0.08$ & $1.61 \pm 0.19^{a, *}$ & $0.80 \pm 0.07^{\mathrm{b}, *}$ & $1.18 \pm 0.10^{\mathrm{b}, * \mathrm{c}, *}$ & $0.73 \pm 0.07$ \\
\hline
\end{tabular}

Notes: Values are expressed as mean \pm SD for six animals. Comparisons are made between: a Group 2 vs Group I; 'Groups 3 and 4, vs Group 2; ' Group 4 vs Group 3; ${ }^{\mathrm{d}}$ Group 5 vs Group I; *statistical significance at $P<0.05$.

neutrophils and monocytes, and a shortened circulation time of lymphocytes, which increases the susceptibility to infection. The raised leukocyte count may also reflect low-grade inflammation. Accelerated erythrocyte sedimentation and the resulting hyperviscosity are predictors of coronary heart disease..$^{41}$ The decrease in the WBC count, platelet count, and ESR in Group 3 animals shows the anti-inflammatory property of the drug which may be due to the presence of polyphenols. ${ }^{42}$

The cytotoxicity of a xenobiotic can be evaluated using marker enzymes. Of all the macromolecules that leak from the damaged tissue, enzymes, owing to their tissue specificity and catalytic activity, are the best markers of tissue damage. The change in alanine and aspartate transaminase activities may be due to the result of variations in protein metabolism in the tissues due to STZ toxicity. ${ }^{43}$ The significant rise in serum GOT and GPT levels in diabetic rats could be related to the excessive accumulation of amino acids in the serum as a result of amino acid mobilization from protein stores. ${ }^{44}$ The increased gluconeogenesis and ketogenesis may be due to high level of these transaminases. ${ }^{45}$ The decreased levels of GOT and GPT after supplementation with SA indicates the restoration of normal liver function. Diabetic rats showed a significant increase in serum alkaline phosphatase activity which indicates the loss of membrane integrity. ${ }^{46}$ The present finding that the liver is necrotized in STZ-diabetic rats is in accordance with earlier reports. ${ }^{47}$

Hyperglycemia may play an important role in the liver function abnormalities and an association exists between diabetes and liver injury. ${ }^{48}$ The increased activity of ALP in Group 2 animals and the subsequent decrease upon SA administration indicates the membrane stabilizing property of the drug. Serum GGT shows a strong graded relation with diabetes, ${ }^{49}$ which suggests its role in the pathogenesis of the disease. The increased activity of GGT observed in the present study may be attributed to the administration of STZ, which is capable of altering the redox balance of the cell by drastic reduction of GSH in the tissues. ${ }^{48}$ The hepatic level of adenosine 3',5'-monophosphate is increased in STZ-treated diabetic rats as a compensatory mechanism to avoid an excessive amount of nucleotides in blood circulation. ${ }^{50}$ Determination of serum bilirubin represents an index for the assessment of hepatic function. Increased bilirubin production, enhanced hepatic conjugation, and biliary excretion of the pigment present in diabetic animals ${ }^{51}$ may be as a result of decreased uptake, conjugation, or increased bilirubin production..$^{52}$ The decreased level of bilirubin in Group 3 animals upon treatment confi rms the hepatoprotective effect of the drug in STZ-induced diabetic animals.

Table 3 Urinary excretion of urea, uric acid, creatinine and albumin in control and experimental animals

\begin{tabular}{|c|c|c|c|c|c|}
\hline Parameters & $\begin{array}{l}\text { Group I } \\
\text { (control) }\end{array}$ & $\begin{array}{l}\text { Group } 2 \\
\text { (STZ) }\end{array}$ & $\begin{array}{l}\text { Group } 3 \\
(\text { STZ + SA) }\end{array}$ & $\begin{array}{l}\text { Group } 4 \\
\text { (STZ } \\
\text { + metformin) }\end{array}$ & Group 5 (SA) \\
\hline Urea (mg/24 hr urine) & $13.04 \pm 1.92$ & $23.34 \pm 2.69^{\mathrm{a}, *}$ & $16.04 \pm 1.55^{\mathrm{b}, *}$ & $19.4 \pm 1.76^{b, *, c, *}$ & $13.5 \pm 1.44$ \\
\hline Uric acid (mg/24 hr urine) & $3.56 \pm 0.34$ & $8.44 \pm 0.92^{\mathrm{a}, *}$ & $4.76 \pm 0.42^{\mathrm{b}, *}$ & $7.66 \pm 0.54^{\mathrm{b}, *, c, *}$ & $3.58 \pm 0.32$ \\
\hline Creatinine (mg/24 hr urine) & $8.39 \pm 0.79$ & $16.13 \pm 1.72^{\mathrm{a}, *}$ & $9.07 \pm 0.93^{\mathrm{b}, *}$ & $13.75 \pm 1.32^{b, *, c, *}$ & $8.5 I \pm 0.94$ \\
\hline Albumin ( $\mu g / 24 \mathrm{hr}$ urine) & $302.75 \pm 29.36$ & $973.43 \pm 93.36^{a, *}$ & $344.64 \pm 36.4^{\mathrm{b}, *}$ & $623.45 \pm 54.8^{\mathrm{b}, *, \mathrm{c}, *}$ & $306.91 \pm 32.3$ \\
\hline
\end{tabular}

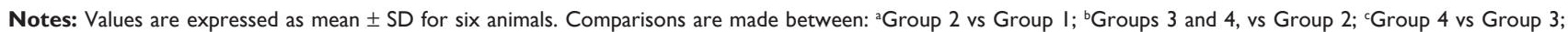
${ }^{\mathrm{d}}$ Group 5 vs Group I; *statistical significance at $P<0.05$. 


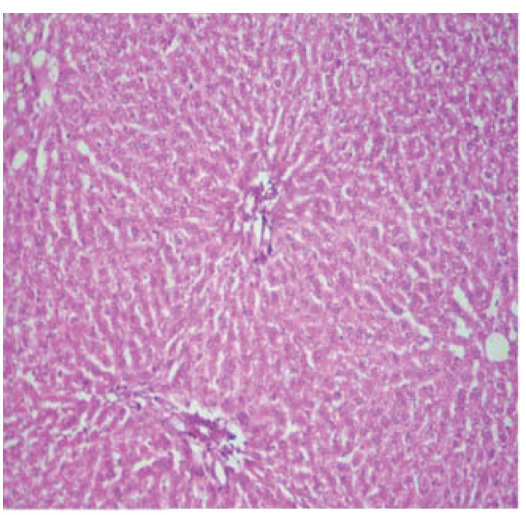

(A)

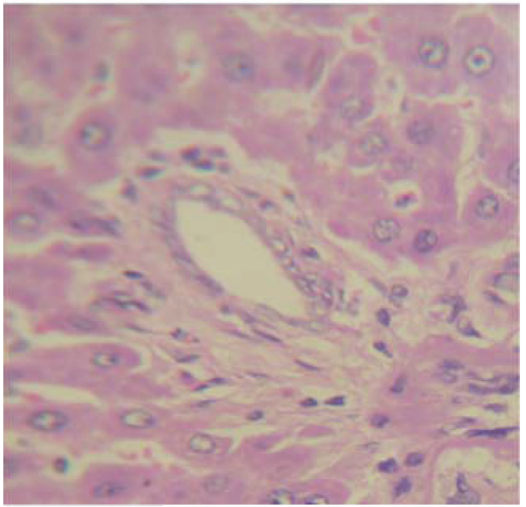

(C)

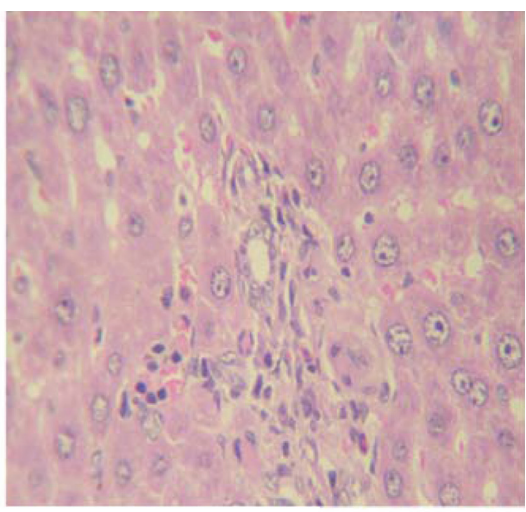

(B)

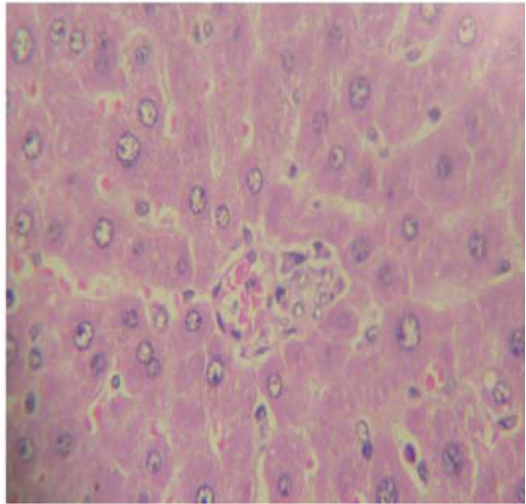

(D)

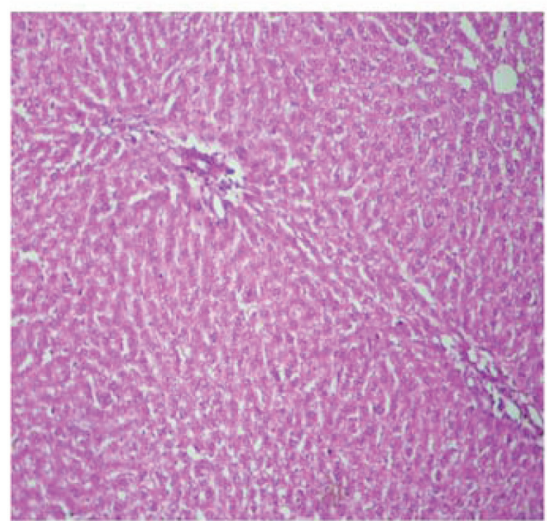

(E)

Figure 4 Histopathological observations in the liver of control and experimental animals.

(A) Group I. Control

(B) Group 2.STZ induced

(C) Group 3.SA-treated

(D) Group 4. Metformin-treated

(E) Group 5.SA drug control
Control section shows normal histology of liver (100x)

This section shows periportal chronic inflammatory infiltrate with focal fatty change (100x).

SA-treated animals shows moderate reduction in periportal chronic inflammatory infiltrate when compared to STZ induced (100x). Metformin-treated section shows marked reduction of periportal chronic inflammatory infiltrate when compared to STZ induced (100x). The section shows normal histology of liver (100x)
An increased albumin excretion rate leading to microalbuminuria is widely acknowledged as the earliest index of diabetic nephropathy and as a risk factor for the development of overt diabetic renal and macrovascular disease..$^{53}$ The decreased albumin excretion seen in SA-treated animals proves the renoprotective effect of the drug, which may be due to the downregulation of various autocrine and paracrine factors such as transforming growth factor beta (TGF- $\beta$ ), insulin-like growth factor 1 (IGF-1), type IV collagen and upregulation of renin. In rats, uncontrolled diabetes mellitus increases corticosterone production and urea excretion..$^{54}$ The decreased levels of serum and urine urea after treatment with 
SA is consistent with earlier reports on herbal drugs for the treatment of diabetes. ${ }^{55}$ The increased excretion and uric acid synthesis can be related to the energetic deficiency in the cells that are unable to utilize glucose in the state of insulin deficiency. This can lead to excessive dephosphorylation of high-energy purine nucleotides (ATP) and their enhanced catabolism with uric acid as an end product. ${ }^{56}$ Increased renal excretion of uric acid in patients with overt diabetes may be due to increased tubular secretion of urate, impaired glomerular filtration rate, or proximal tubule alteration. ${ }^{57}$ The metabolic and microvascular complications of diabetes are associated with multiple effects on renal function and creatinine metabolism. Extreme hyperglycemia, osmotic diuresis, and depletion of extracellular fluid volume may cause a decline in glomerular filtration rate (GFR) and an increase in serum creatinine. In diabetes, there is a relationship between glucose homeostasis and renal damage which can be confirmed by the elevation of the serum creatinine. ${ }^{58}$ Treatment with SA reversed the alterations caused by STZ and increased glycemia, which could be due to the reduction of hyperfiltration, alteration in GFR by decreasing the hemodynamically mediated renal injury and by improving the glycemic control. The absence of structural and morphological changes of kidney in the drug control Group 5 proves the nontoxic nature of SA.

The release of cellular enzymes reflects a nonspecific alteration in the plasma membrane integrity and/or permeability as a response to STZ administration. The altered activities of the marker enzymes in the serum and tissues of the control and experimental animals may be due to the presence of flavonoids in SA which have membrane-stabilizing properties. Sanz et a ${ }^{59}$ have reported that natural flavonoids present in medicinal plants have the ability to decrease serum transaminase activity in animals. The presence of flavonoids may be responsible for these beneficial effects.

\section{Disclosure}

The authors report no conflicts of interest.

\section{References}

1. Kameswara Rao B, Renuka Sudarshan P, Rajasekhar MD, Nagaraju N, Appa Rao Ch. Antidiabetic activity of Terminalia pallida fruit in alloxan induced diabetic rats. J Ethnopharmacol. 2003;85:169-172.

2. Winer S, Tsui H, Lau A, Song A, Li X, Cheung RK, et al. Autoimmune islet destruction in spontaneous type 1 Diabetes is not beta-cell exclusive. Nat Med. 2003;9:198-205.

3. Ashcroft FM, Proks P, Smith PA, Ammälä C, Bokvist K, Rorsman P. Stimulus-secretion coupling in pancreatic beta cells. Cell Biochem. 1994;55 Suppl:54-65.

4. Schnedl WJ, Ferber S, Johnson JH, Newgard CB. STZ transport and cytotoxicity. Specific enhancement in GLUT2-expressing cells. Diabetes. 1994;43:1326-1333.
5. Modak MA, Datar SP, Bhonde RR, Ghaskadbi SS. Differential susceptibility of chick and mouse islets to streptozotocin and its co-relation with islet antioxidant status. J Comp Physiol [B]. 2007; 177:247-257.

6. Lenzen S. The mechanisms of alloxan- and streptozotocin-induced Diabetes. Diabetologia. 2008;51:216-226.

7. Szkudelski T. The mechanism of alloxan and streptozotocin action in B cells of the rat pancreas. Physiol Res. 2001;50:537-546.

8. Kesari AN, Gupta RK, Watal G. Hypoglycemic effects of Murraya koenigii on normal and alloxan-diabetic rabbits. J Ethnopharmacol. 2005;97:247-245.

9. Phatak MK, Ambaye RY, Indap MA, Bhatia KG. Cytotoxicity of the acetylated oil of Semecarpus anacardium Linn. F. Indian Pract. 1983;26:253.

10. Indap MA, Ambaye RY, Gokhale SV. Potentiation of activity of anticancer drugs by acetylated oil of Semecarpus anacardium Linn. f. in experimental tumors. Indian Drugs. 1986;23:447.

11. Prakash Rao NS, Ramachandra Row L, Brown RT. Phenolic constitutents of Semecarpuas anacardium. Phytochemistry. 1973;12:671-681.

12. Gedam PH, Sampathkumaran PS, Sivasamban A. Composition of bhilawanol from Semecarpus anacardium. Phytochem. 1974;13: 513-515.

13. Murthy SSN. New bioflavonoid from Semecarpus anacardium Linn. Clin Acta Turcica. 1992;20:33-37.

14. Vijayalakshmi T, Muthulakshmi V, Sachdanandam P. Toxic studies on biochemical parameters carried out in rats with Serankottai nei, a siddha drug-milk extract of Semecarpus anacardium nut. J Ethnopharmacol. 2000;69:9-15.

15. Saraf MN, Ghooi RB, Patwardhan BK. Studies on the mechanism of action of Semecarpus anacardium in rheumatoid arthritis. J Ethnopharmacol. 1989;25:159-164.

16. Premalatha B. Semecarpus anacardium Linn. Nuts $-A$ boon in alternative medicine. Ind J Exp Biol. 2000;38:1177-1182.

17. Arul B, Kothai R, Christina AJ. Hypoglycemic and antihyperglycemic effect of Semecarpus anacardium Linn in normal and streptozotocin-induced diabetic rats. Methods Find Exp Clin Pharmacol. 2004;26: 759-762.

18. Ramprasath VR, Shanthi P, Sachdanandam P. Evaluation of antioxidant effect of Semecarpus anacardium Linn. nut extract on the components of immune system in adjuvant arthritis. Vasc Pharmacol. 2005;42:179-186.

19. Selvam C, Jachak SM. A cyclooxygenase (COX) inhibitory biflavonoid from the seeds of Semecarpus anacardium. J Ethnopharmacol. 2004; 95:209-212.

20. Formulary of Siddha Medicine, 2nd edition. Published by the Indian Medicine Practitioners Co-operative Pharmacy and stores Ltd., Madras, India, 1972: p197.

21. Chesbrough M, McArthur J. In: A laboratory manual for rural tropical hospital. The English language book society and Churchill Livingstone 1972. p. 145.

22. Dacie JV, Lewis SM. In: Practical haematology. (1977). Churchill Livingstone (eds), Edinburgh.

23. Wintrobe MM. Macroscopic examination of the blood in retrospect. Am J Med Sci. 1976;271:103-105.

24. Westergren. In: Medical laboratory technology, Mukherjee KL, editor, Tata McGraw-Hill publishing Company Ltd., New Delhi, India, 1988. Vol.1, p. 293.

25. Drabkin DLR, Austin JN. Spectrophotometric studies, Spectrophotometric constants for common hemoglobin derivatives in human, dog and rabbit blood. J Biol Chem. 1932;98:719-733.

26. King J. The transferases alanine and aspartate tranaminases. In: van D, editor. Practical Clinical Enzymology. London: Nostrand Company Limited; 1965:121-138.

27. King J. The phosphohydrolases - acid and alkaline phosphatases. In: van D, editor. Practical Clinical Enzymology. London: Nostrand Company Limited; 1965:191-208.

28. Orlowski M, Meister A. Isolation of gamma-glutamyl transpeptidase from hog kidney. J Biol Chem. 1965;240:338-347. 
29. Luly P, Barnabei O, Tria E. Hormonal control in vitro of plasma membrane bound (Na+-K+)-ATPase of rat liver. Biochim Biophys Acta. 1972;282:447-452.

30. Fine J. The biuret method of estimating albumin and globulin in serum and urine. Biochem J. 1935;29:799-803.

31. Dangerfield WG, Finlayson R. Estimation of bilirubin in serum. J Clin Path. 1953;6:173.

32. Henry RJ, Chiamori N. Determination of $\alpha$-amylase activity in plasma and urine of pancreatic diseases. Clin Chem. 1960;6:434-441.

33. Natelson S, Scott ML, Beffa C. A rapid method for the estimation of urea in biological fluid by means of the reaction between diacetyl and urea. Am J Clin Pathol. 1951;21:275-281.

34. Caraway WT. Uric acid. In: Seligson D, editor. Standard methods of clinical chemistry. New York: Academic Press; 1963:239-247.

35. Owen JA, Iggo B, Scandrett FJ, Stewart CP. The determination of creatinine in plasma or serum, and in urine; a critical examination. Biochem J. 1954;58:426-437.

36. Kozlov IuA, Novitskiı̌ VV, Baǐkov AN. [Kinetics of blood leukocytes in mice with alloxan diabetes]. Biull Eksp Biol Med. 1995;120:33-35.

37. Cheeke PR. Natural toxicants in feeds, forages and poisonous plants 2nd ed. Danville, IL: Interstate Publishers; 1998.

38. Moussa EA. Effects of 1,4- dioxane on some blood parameters of the Swiss albino mice. Scientific Journal of King Faisal University (Basic and Applied Sciences) 2004;5:1425.

39. Stookey JD, Burg M, Sellmeyer DE, et al. A proposed method for assessing plasma hypertonicity in vivo. Eur J Clin Nutr. 2007;61: 143-146.

40. McGuire M, MacDermott M. The influence of streptozotocin diabetes and metformin on erythrocyte volume and on the membrane potential and the contractile characteristics of the extensor digitorum longus and soleus muscles in rats. Exp Physiol. 1999;84:1051-1058.

41. Danesh J, Collins R, Peto R, Lowe GD. Haematocrit, viscosity, erythrocyte sedimentation rate: meta-analyses of prospective studies of coronary heart disease. Eur Heart J. 2000;21:515-520.

42. Ramprasath VR, Shanthi P, Sachdanandam P. Anti-inflammatory effect of Semecarpus anacardium Linn. Nut extract in acute and chronic inflammatory conditions. Biol Pharm Bull. 2004;27:2028-2031.

43. Singh SN, Vats P, Suri S, et al. Effect of an antidiabetic extract of Catharanthus roseus on enzymic activities in streptozotocin induced diabetic rats. J Ethnopharmacol. 2001;76:269-277.

44. Colev V, Bădescu M, Păduraru I, Mândreci I, Bohotin C. [The zinc-metabolic disorder relation in experimental Diabetes mellitus]. Rom J Intern Med. 1994;32:71-75.

45. Maiti R, Jana D, Das UK, Ghosh D. Antidiabetic effect of aqueous extract of seed of Tamarindus indica in streptozotocin-induced diabetic rats. J Ethnopharmacol. 2004;92:85-91.
46. Shahraki MR, Arab MR, Mirimokaddam E, Palan MJ. The effect of Teucrium polium (Calpoureh) on liver function, serum lipids and glucose in diabetic male rats. Iran Biomed J. 2007;11:65-68.

47. Ozsoy-Sacan O, Yanardag R, Orak H, Ozgey Y, Yarat A, Tunali T. Effects of parsley (Petroselinum crispum) extract versus glibornuride on the liver of streptozotocin-induced diabetic rats. J Ethnopharmacol. 2006;104:175-181.

48. Arkkila PE, Koskinen PJ, Kantola IM, Rönnemaa T, Seppänen E, Viikari JS. Diabetic complications are associated with liver enzyme activities in people with type 1 diabetes. Diabetes Res Clin Pract. 2001; 52:113-118

49. Lee DH, Ha MH, Kim JH, et al. (a) Gamma-glutamyltransferase and diabetes: a 4 year follow-up study. Diabetologia. 2003;46:359-364.

50. Lunkes GI, Lunkes DS, Leal D, et al. Effect of high glucose levels in human platelet NTPDase and 5'-nucleotidase activities. Diabetes Res Clin Pract. 2008;81:351-357.

51. Sudnikovich EJ, Maksimchik YZ, Zabrodskaya SV, et al. Melatonin attenuates metabolic disorders due to streptozotocin-induced diabetes in rats. Eur J Pharmacol. 2007;569:180-187.

52. El-Demerdash FM, Yousef MI, El-Naga NI. Biochemical study on the hypoglycemic effects of onion and garlic in alloxan-induced diabetic rats. Food Chem Toxicol. 2005;43:57-63.

53. Valmadrid CT, Klein R, Moss SE, Klein BE. The risk of cardiovascular disease mortality associated with microalbuminuria and gross proteinuria in persons with older-onset diabetes mellitus. Arch Intern Med. 2000;160:1093-1100.

54. Mitch WE, Bailey JL, Wang X, Jurkovitz C, Newby D, Price SR. Evaluation of signals activating ubiquitin-proteasome proteolysis in a model of muscle wasting. Am J Physiol. 1999;276:C1132-C1138.

55. Eidi A, Eidi M, Darzi R. Antidiabetic effect of Olea europaea L. in normal and diabetic rats. Phytother Res. 2009;23:347-350.

56. Metzler B, Schocke MF, Steinboeck P, et al. Decreased high-energy phosphate ratios in the myocardium of men with diabetes mellitus type I. J Cardiovasc Magn Reson. 2002;4:493-502.

57. Gołembiewska E, Ciechanowski K, Safranow K, Kedzierska K, KabatKoperska J. Renal handling of uric acid in patients with type 1 diabetes in relation to glycemic control. Arch Med Res. 2005;36:32-35.

58. Eidi A, Eidi M, Esmaeili E. Antidiabetic effect of garlic (Allium sativum L.) in normal and streptozotocin-induced diabetic rats. Phytomedicine. 2006;13:624-629.

59. Sanz MJ, Ferrandiz ML, Cejudo M, et al. Influence of a series of natural flavonoids on free radical generating systems and oxidative stress. Xenobiotica. 1994;24:689-699.
Journal of Experimental Pharmacology

\section{Publish your work in this journal}

The Journal of Experimental Pharmacology is an international, peerreviewed, open access journal publishing original research, reports, reviews and commentaries on all areas of laboratory and experimental pharmacology. The manuscript management system is completely online and includes a very quick and fair peer-review system.

\section{Dovepress}

Visit http://www.dovepress.com/testimonials.php to read real quotes from published authors. 